\title{
EFFECTS OF ARAK BALI ADMINISTRATION ON SPERMATOZOA DNA FRAGMENTATION AND TESTOSTERONE LEVEL OF RATS (Rattus norvegicus)
}

\author{
Alfiah Hayati, Dwi Winarni, Ni Wayan Sukma Antari, Inne Ninda Resita, Erlyn Nurul Fauziah \\ Department of Biology, Faculty of Science and Technology, Universitas Airlangga, Surabaya
}

\begin{abstract}
ABSTRAK
Penelitian ini bertujuan untuk mengetahui pengaruh pemberian arak bali terhadap fragmentasi DNA spermatozoa dan kadar testosteron tikus (Rattus norvegicus). Penelitian ini menggunakan 24 ekor tikus (170-200 g), dibagi menjadi empat kelompok: satu kontrol dan tiga perlakuan (diberi arak bali yang mengandung 40\% alcohol sebanyak 0,1 dan 0,5 mL serta alkohol sintetis (40\%) sebanyak 0,1 mL, selama 45 hari. Pengamatan DNA fragmentasi menggunakan pewarnaan acridine orange dan pengukuran kadar testosteron menggunakan metode ELISA. Hasil penelitian menunjukan bahwa pemberian arak bali pada hewan coba meningkatkan terjadinya fragmentasi DNA spermatozoa. Semakin besar volume arak bali yang diberikan, semakin tinggi fragmentasi DNA spermatozoa. Pemberian arak bali juga menurunkan kadar testosteron. Semakin besar volume arak bali yang diberikan, semakin rendah kadar testosteron tikus. (FMI 2018;54:41-45)
\end{abstract}

Kata kunci: Arak bali; fragmentasi DNA spermatozoa; testosteron; tikus (Rattus norvegicus)

\begin{abstract}
This study aimed to determine the effects of arak bali on the fragmentation of spermatozoa and testosterone in rats (Rattus norvegicus). This study used 24 rats (170-200 g), divided into four groups: one control and three treatments (receiving arak bali containing $40 \%$ alcohol as much as 0.1 and $0.5 \mathrm{~mL}$ and synthetic alcohol (40\%) as much as $0.1 \mathrm{~mL}$, for 45 days). The observation of DNA fragmentation was done using acridine orange staining and the measurement of testosterone level used ELISA method. The results showed that the provision of arak bali in experimental animals increased the occurrence of spermatozoa DNA fragmentation. The higher the volume of arak bali given, the higher the fragmentation of spermatozoa DNA. The administration of arak bali also decreased testosterone level. The higher the volume of arak bali given, the lower the rats' testosterone level. (FMI 2018;54:41-45)
\end{abstract}

Keywords: Arak bali; spermatozoa DNA fragmentation; testosterone; rats (Rattus norvegicus)

Correspondence: Alfiah Hayati, Department of Biology, Faculty of Science and Technology, Universitas Airlangga, Campus C, Mulyorejo, Surabaya, Indonesia. Email: alfiahayati64@yahoo.com

\section{INTRODUCTION}

Bali is an island with a variety of customs that are still sustainable to date. One of the customs that is preserved to date is presenting traditional drinks in every religious ceremony. Like traditional liquor, this drink is used as a complement to religious ceremonies. In addition to the ceremony, liquor is also consumed by the people of Bali. Arak, or traditional liquor, is usually made from fermented coconut water, nira (aren) fruit and rice water. This liquor has quite high alcohol content, so the liquor is divided into several grade levels. For grade I, it has alcohol content above 35\%, class II has alcohol content $35=x=25 \%$, while for class III, it has alcohol content of less than 25\% (Lempang 2006).

Alcohol that enters the body will undergo a series of biochemical processes. Out of all alcohol consumed, $90 \%$ will be metabolized by the body, especially in the liver, by alcohol-dehenogenase (ADH) enzyme and nicotinamide-adenine-dinucleotide (NAD) coenzyme to acetaldehyde, and then by aldehyde dehydrogenase (ALDH) enzyme, it is converted to acetic acid. Alcohol metabolism in the liver involves three pathways: cytosolic, peroxisome, and microsomal pathways. Thee cytosol pathway mechanism is an oxidation process involving alcohol dehydrogenase (ADH) enzyme. Alcohol metabolism by ADH will produce acetaldehyde, which is a highly reactive and toxic product that may cause damage to some tissues and cells. The mechanism of peroxisome pathway involves the hydrogen produced from alcohol metabolism that leads to changes in fat and carbohydrate metabolisms that result in the increase of collagen tissue, and, in certain circumstances, can inhibit protein synthesis. The microsomal pathway lies within endoplasmic reticulum. With the help of P-450 cytochrome enzyme, alcohol is decomposed into acetaldehyde. The alcohol is converted to acetaldehyde, then converted to acetate by aldehyde dehydrogenase in mitochondria. Alcohol use for long periods of time will cause changes in mitochondria, leading to reduced capacity for fat oxidation (Zakhari 2006). 
The accumulation of acetaldehyde compounds resulting from excessive alcohol consumption will lead to increased reactive oxygen species (ROS) in the body (Zakhari 2006). ROS compounds are produced naturally in small amounts during the body's metabolic reactions and can react with cellular molecules and complex damage, such as fat, protein, or DNA. Toxic compounds produced from alcohol metabolism can increase reactive oxygen species (ROS) and interfere with the body's normal defense mechanisms against these compounds through various processes, especially in the liver. Alcohol also stimulates the activity of an enzyme called cytochrome $\mathrm{P}-450$, which contributes to the production of ROS.

High levels of ROS in the body can result in lipid peroxidation, an oxidative reaction that breaks off unsaturated fats into malondialdehyde (MDA). Lipid peroxidation in cells can affect the integrity of cell membranes that will lead to decreased quality of spermatozoa (Hayati 2011). Lipid peroxidation may also occur in Leydig cells, which may interfere with the function of Leydig cells to produce testosterone. Decreased testosterone can lead to negative and positive feedback on the hypothalamus that can lead to a decrease in the amount of FSH and LH secretion by the anterior pituitary resulting in decreased secretion of testosterone hormone by Leydig cells which in turn will trigger the occurrence of infertility.

Thus, it is necessary to study infertility test by observing testosterone levels and the occurrence of spermatozoa DNA fragmentation of the experimental animals, i.e. male rats (Rattus norvegicus), by providing a traditional alcoholic beverage, arak bali.

\section{MATERIALS AND METHODS}

This study was conducted in two stages. The first stage was distributing questionnaires in five regencies in Bali, namely Badung, Gianyar, Tabanan, Karangasem and Denpasar. The distribution of questionnaire aimed to find out the type of arak bali that was often consumed and the frequency of its consumption. The second stage was giving treatment to experimental animals, the white rats (Rattus norvegicus) with body weight of 170-250 gram and age of 3 month. A total of 24 rats were divided into four groups. Each group consisted of six replicates (6 rats). One control group was given with only $0.1 \mathrm{~mL}$ of water and three treatment groups was given varied volumes of arak bali containing $40 \%$ alcohol $(0.1$ and $0.5 \mathrm{~mL})$ and $40 \%$ synthetic alcohol of $0.5 \mathrm{~mL}$. Each of the rats was administered orally every day for 45 days.

\section{Collection of epididymal spermatozoa}

After the treatment of arak bali for 45 days was completed, then on day 46 , the rats were sacrificed and dissected. Furthermore, the right and left testicles were taken and cleared from the fat tissue. Then, cidal epididymis was separated from the testes. Spermatozoa collection was performed by making spermatozoa suspension by chopping small epididymis in $2 \mathrm{~mL}$ physiological saline solution $(0.9 \% \mathrm{NaCl}), \mathrm{pH} 7.2-7.4$. Thus, the spermatozoa suspension was ready to be tested for spermatozoa DNA fragmentation.

\section{Calculation of DNA fragmentation}

Fragmentation of spermatozoa DNA was observed using cytochemical test, Acridine Orange (AO). The smoothed sperm had been fixed overnight using a solution of Carnoys (methanol and glacial acetic acid $3: 1)$. The slides were diluted and given with working solution of AO (10 ml 1\% AO, $40 \mathrm{~mL}$ citric acid, 2.5 $\mathrm{mL} \mathrm{Na} 2 \mathrm{HPO} 4.7 \mathrm{H} 2 \mathrm{O} 0.3 \mathrm{M} \mathrm{pH} \mathrm{2.5)} \mathrm{for} 5 \mathrm{~min}$ at room temperature and dark condition to test chromatin stability. Furthermore, the slides were stained with $1 \%$ acridine orange dye $(100 \mathrm{mg} / \mathrm{ml})$, then observed under a fluorescence microscope. Green color showed normal doublestranded DNA, whereas orange or red color indicated DNA fragmentation (Evenson et al 2002).

\section{Measurement of testosterone levels}

Testosterone levels were calculated by blood sampling. Blood was taken as much as $0.25 \mathrm{~mL}$ from the left ventricle of the heart using disposable syringe. To obtain serum, rat blood was centrifuged for $10 \mathrm{~min}$ at $3000 \mathrm{rpm}$. The obtained serum was stored at $-20^{\circ} \mathrm{C}$. Testosterone levels were calculated using the Enzyme Linked Immunosorbent Assay (ELISA) technique. ELISA method used microplate (well) as the place or container. Sample and standard solution were put into well and incubated for $30 \mathrm{~min}$. After that, it was washed with $100 \mu \mathrm{l}$ wash solution. The plate was shaken to obtain homogeneous results. The liquid was removed by absorbing the liquid using a tissue. After that 50 $\mu 1$ HRPconjugate reagent was added into each well (except blank well). It was incubated for $30 \mathrm{~min}$ at $37^{\circ} \mathrm{C}$. After incubation, it was added with $50 \mu \mathrm{l}$ of chromogen $\mathrm{A}$ and chromogen B mixture to well. After that, it was incubated for 15 minutes at $37^{\circ} \mathrm{C}$ and isolated from light. It was also added with $50 \mu \mathrm{l}$ stop solution, homogenized, then observed for color change (blue to yellow) (Ahangarpour et al 2014). To identify the absorbance value, ELISA reader at $450 \mathrm{~nm}$ wavelength was used. 


\section{RESULTS}

\section{The influence of arak bali on spermatozoa DNA fragmentation}

The results showed that the provision of arak bali caused structural abnormalities of rat spermatozoa DNA. This was demonstrated by the use of acridine orange (AO) staining which showed that many DNA spermatozoa were fragmented. The more volumes of arak bali given, the more fragmented the spermatozoa DNA. In Fig. 1.B, the color of orange appears in the head of spermatozoa. The appearance of this color indicated the presence of DNA fragmentation located in the nucleus of spermatozoa cells. The number of rats spermatozoa that had DNA fragmentation after giving variation of arak bali volume containing $40 \%$ alcohol can be seen in Fig. 2.
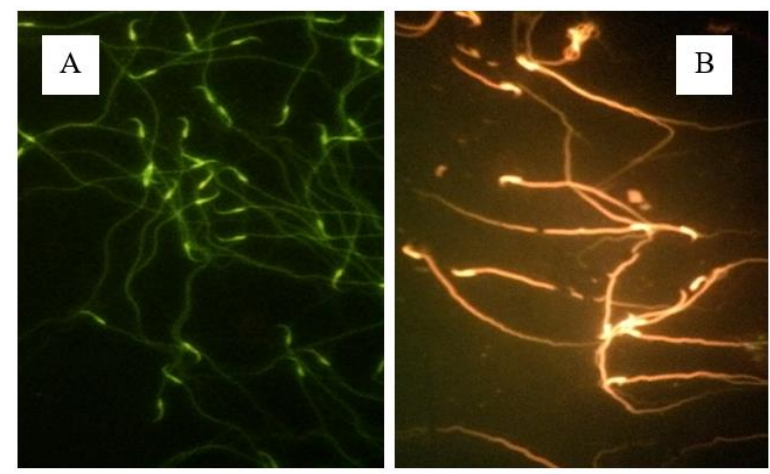

Fig. 1. Spermatozoa of rats with acridine orange staining. Spermatozoa with normal DNA is characterized by green (A), fragmented nuclear DNA is characterized by orange (B).

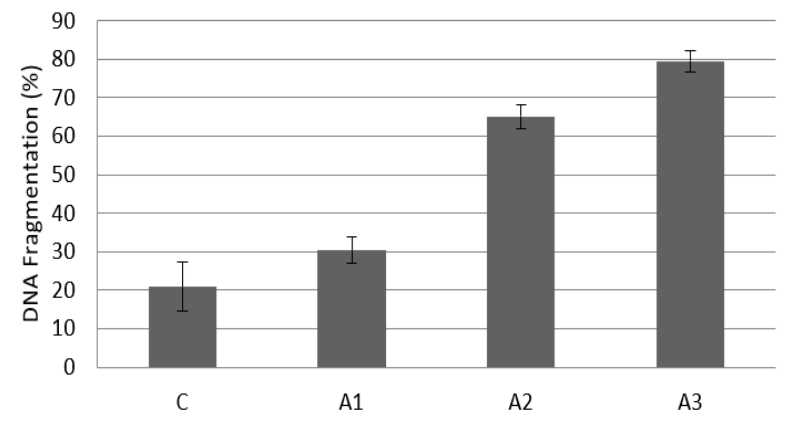

Fig. 2. Fragmentation of nuclear DNA of spermatozoa after the administration of $40 \%$ arak bali. $\mathrm{C}=$ control without alcohol, $\mathrm{A} 1$ and $\mathrm{A} 2=0.1$ and 0.5 $\mathrm{mL}$ arak bali, $\mathrm{A} 3=0.1 \mathrm{~mL}$ of $40 \%$ synthetic alcohol.
The lowest percentage of spermatozoa DNA with the lowest fragmentation was seen in control group compared with the other treatment groups (A1-A3). Under normal circumstances (control), there appears to be DNA fragmentation $(20.96 \%)$. However, the provision of $40 \%$ arak bali as much as $0.1 \mathrm{~mL}$ daily for 45 days can increase spermatozoa DNA fragmentation (30.44\%). The higher the volume of arak bali, the higher the spermatozoa DNA damage (65.12\%). However, in this study, the administration of synthetic alcohol $(40 \%)$ for 45 days as much as $0.1 \mathrm{~mL}$ resulted in highest percentage of DNA damage or fragmentation (79.52\%) (Fig. 2).

\section{The influence of arak bali on testosterone levels}

Measurements of testosterone levels were performed using Enzyme Linked Immunosorbent Assay (ELISA) method. The absorbance value of ELISA results was calculated using ELISA reader at $450 \mathrm{~nm}$ wavelength. The results of measurement of testosterone levels are presented in Fig. 3.

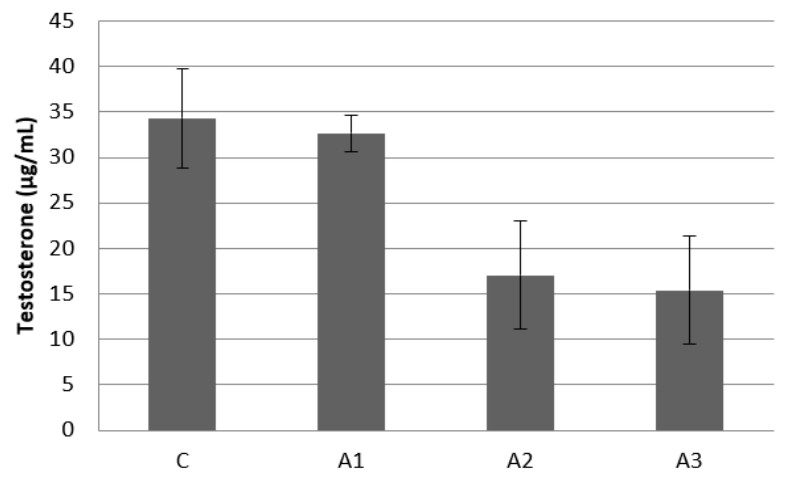

Fig. 3. Levels of rat testosterone after the administration of arak bali containing 40\% alcohol. C $=$ control without alcohol, $\mathrm{A} 1$ and $\mathrm{A} 2=0.1$ and $0.5 \mathrm{~mL}$ arak bali, $\mathrm{A} 3=0.1 \mathrm{~mL} 40 \%$ synthetic alcohol.

Fig. 3 shows decrease in testosterone levels by increasing the volume of arak bali. Rats' testosterone levels in control group were about $34.29 \mu \mathrm{g} / \mathrm{mL}$. Whereas, after the administration of 0.1 and $0.5 \mathrm{~mL}$ arak bali for 45 days, the testosterone levels decreased of 32.68 and $17.04 \mu \mathrm{g} / \mathrm{mL}$ respectively. Treatment group with $40 \%$ synthetic alcohol as much as $0.1 \mathrm{~mL}$ showed that testosterone levels also decreased $(15.38 \mu \mathrm{g} / \mathrm{mL})$. Significant decrease in testosterone levels $(\mathrm{P}<0.05)$ occurred in the administration of arak bali as much as $0.5 \mathrm{ml}$ and 0.1 $\mathrm{mL}$ of synthetic alcohol as compared to control group. There was no significant difference $(\mathrm{P}>0.05)$ on the decrease of testosterone levels after the administrations of $0.5 \mathrm{~mL}$ arak bali and $0.1 \mathrm{~mL}$ synthetic alcohol. 


\section{DISCUSSION}

\section{The influence of arak bali on spermatozoa DNA fragmentation}

The fragmentation of spermatozoa DNA in group of rats administered with $0.5 \mathrm{~mL}$ arak bali and in group of rats administered with $0.1 \mathrm{~mL}$ alcohol showed high spermatozoa DNA fragmentation, compared to the control group and the group that was administered with $0.1 \mathrm{~mL}$ arak bali. The fragmentation of spermatozoa DNA was characterized by orange color on the head and tail of spermatozoa observed using fluorescence microscope, whereas the intact DNA was characterized by green color on the head and tail of spermatozoa. AO staining was used to measure spermatozoa nuclear DNA capacity. This DNA structure underwent acidity changes. Thus, by using flouresence microscope, it shows a change of color from green (normal DNA) to orange (fragmented DNA). Normal double-helix DNA structure that binds with AO may show green fluoresence, while AO that binds with denaturated DNA may show orange fluoresence (Essam-Elden et al 2015).

The fragmentation of spermatozoa nuclear DNA occurs due to high levels of ROS. The source of this ROS compound come from alcohol contained in arak bali, thus affecting nuclear DNA structure of spermatozoa. In addition, ROS also affects the integrity of spermatozoa cell membranes, thereby decreasing fertility. This is because the spermatozoa plasma membrane consists of a double lipid containing unsaturated fatty acids that are particularly susceptible to ROS, resulting in lipid peroxidation of the spermatozoa membrane. The preparation of nuclear DNA of mammalian spermatozoa is regulated by protamine molecules during spermiogenesis. In this phase, specific sperm histones are replaced by protamine, which is rich in cysteine and amino acids. During the course of the sperm to the epididymis, the cysteine-thiol group of protamine molecules is oxidized into the obligated disulfide (SES), which is necessary for the stability of sperm chromatin formation. Protamine is a major protein in the nucleus of spermatozoa that binds to DNA. Protamine plays an important role for the formation of necessary chromatin in the normal function of spermatozoa (Szczygiel \& Ward 2002). Abnormal expression of protamine causes decrease in the number of spermatozoa, decreases motility and morphology of spermatozoa, increases spermatozoa chromatin damage (Mengual et al 2003), decreases spermatozoa viability, increases spermatozoa DNA damage and male infertility.

According to Sakkas et al (2003) and Saleh and Agarwal (2002), one factor responsible for spermatozoa chromatin damage is the occurrence of apoptosis.
Alcohol induces apoptosis in testicular germ cells and inhibits spermatogenesis, so it induces sperm chromatin and DNA damage through apoptosis.

\section{The influence of arak bali on testosterone levels}

Testosterone test results showed that arak bali had effect on testosterone level. However, there were no significant differences between control with p1 $(0.1 \mathrm{~mL}$ arak bali) group, and $\mathrm{p} 2$ with $\mathrm{p} 3$ group indicating that the volume of $0.5 \mathrm{~mL}$ arak bali was equivalent to volume of $0.1 \mathrm{~mL}$ synthetic alcohol. This study is in line with the results of a study conducted by Oremosu and Akang (2014) on the influence of alcohol on testosterone. Chronic alcohol consumption affects the work of hypothalamus, resulting in decreased GnRH secretion. Alcohol affects the work of testes through the HPG (hypothalamus-pituitary-gonad) axis pathway.

Consumption of beverages containing high alcohol may increase lipid peroxidation, whereas lipid peroxidant is an oxidative reaction that breaks down unsaturated fatty acids into aldehydes (MDAs). Significant increase in MDA levels results in increased superoxide dismutase in response to increased lipid peroxidation. High-grade lipid peroxidation is a sign of damage to cell membrane. Toxic compound carried by the alcohol will enter through the blood capillaries within the testes. The lipid peroxidation compound (MDA) will damage the membrane of the cells inside testes, where in this case, cells that can be destroyed by MDA are Leydig cells in the seminiferous tubules. High levels of MDA can suppress the function of Leydig cells to secrete testosterone which is essential in spermatogenesis. If testosterone levels decrease, the spermatogenesis process will be impaired and lead to decreased quality of spermatozoa (Saleh \& Agarwal 2002).

\section{CONCLUSION}

The administraton of arak bali containing $40 \%$ alcohol and $40 \%$ synthetic alcohol for 45 days can increase the occurrence of DNA fragmentation and decrease testosterone levels.

\section{REFERENCES}

Ahangarpour A, Oroojan AA, Radan M (2014). Effect of aqueous and hydro-alcoholic extracts of lettuce (Lactuca sativa) seed on testosterone level and spermatogenesis in NMRI mice. J. Reprod Med 12, 65-72

Essam-Elden M, Mosad E, Zahran AM, Hameed DA, Taha EA, Mohamed MA (2015). Acridine orange and 
flow cytometry: which is better to measure the effect of varicocele on sperm DNA integrity? Advances in Urology

Evenson DP, Larson KL, Jost LK (2002). Sperm chromatic structure assay: its clinical use for detecting sperm DNA fragmentation in male infertility and comparisons with the other technique. J Androl 23, $25-43$

Hayati A (2011). Spermatologi. Surabaya, Airlangga University Press

Lempang M (2006). Rendemen dan kandungan nutrisi nata pinnata yang diolah dari nira aren. Jurnal Penelitian Hasil Hutan 24

Mengual L, Ballesca JL, Ascaso C, Oliva R (2003). Marked differences in protamine content and P1/P2 ratios in sperm cells from percoll fractions between patients and controls. J. Andrology 24, 438-447
Oremosu AA, Akang EN (2014). Impact of alcohol on male reproductive hormones, oxidative stress and semen parameters in Sprague-Dawley rats. Middle East Fertility Society Journal 20, 114-118

Saleh RA, Agarwal A (2002). Oxidative stress and male infertility: from research bench to clinical practice. J. Androl 23, 737-752

Szczygiel MA, Ward WS (2002). Combination of dithiothreitol and detergent treatment of spermatozoa causes paternal chromosomal damage. Biology. Reproductive 67, 1532-1537

Sakkas D, Urner F, Bianchi PG, Bizzaro D, Wagner I, Jaquenoud N (2003). Sperm chromatin anomalies can influence decondensation after intracytoplasmic sperm injection. Human Reproductive 11, 837-843

Zakhari S (2006). Overview: How is alcohol metabolized by the body. Alcohol Res. Health 29, 245-254 